UDK: $24: 1$

COPYRIGHT @: SEBASTJAN VÖRÖS

\title{
Misel in neizrekljivo v budistični logično-epistemološki šoli: Nov pogled na teorijo dveh resnic pri Dignāgi in Dharmakīrtiju
}

\author{
Sebastjan VÖRÖS*
}

\section{Izvleček}

Na področju znanstvenega proučevanja filozofije indijskega budizma zasledimo dve struji: prva pojmuje razvoj budistične filozofske misli kot dialektičen proces, medtem ko druga opozarja, da je potekal razvoj budistične filozofije veliko bolj kontinuirano in postopoma. V pričujočem članku bomo znotraj konceptualnega okvirja druge struje prevetrili nekatere filozofske teme, prisotne $\mathrm{v}$ budistični logično-epistemološki šoli, zlasti t.i. teorijo dveh resnic, in nato s pomočjo dobljenih izsledkov pokazali, da je logično-epistemološki sistem Dignāge in Dharmakīrtija tesneje povezan s predhodnimi miselnimi tokovi, kot je to domnevala »dialektična« struja, in ga je zato potrebno umestiti v širši kontekst budistične teorije in prakse, katerih glavni namen je doseganje nirvāṇe. Logično-epistemološki razmisleki $\mathrm{v}$ budizmu ne le, da niso $\mathrm{v}$ nasprotju $\mathrm{z}$ budističnimi duhovnimi prvinami, marveč so z njimi celo neločljivo povezani.

Ključne besede: budizem, budistična filozofija, logika, epistemologija, odrešitev, meditativne tehnike

\begin{abstract}
Studies in Indian Buddhist philosophy have been influenced by two different schools of thought: the first sees the development of Buddhist philosophy as a dialectical process, while the second one sees it as a continuous process. Here, we use the conceptual framework of the latter to illuminate certain philosophical themes present in the Buddhist epistemological school, especially the so-called theory of two truths. Our main goal is to show that the epistemological system of Dignāga in Dharmakīrti was strongly influenced
\end{abstract}

\footnotetext{
* Sebastjan Vörös, doktorski študent, Fakulteta za družbene vede, Univerza v Ljubljani. Elektronski naslov: sebastjan.voros@gmail.com
} 
by previous philosophical trends, and that, in order to understand it correctly, we must place it in the broader context of Buddhist theory and practice with its emphasis on the attainment of nirvāna. Thus, not only are there no inconsistencies between epistemological and spiritual elements in Indian Buddhism, they are, in fact, inextricably interconnected.

\title{
Keywords: Buddhism, Buddhist philosophy, logics, epistemology, liberation, meditative techniques
}

\author{
Nauki različnih bud o Dharmi počivajo na \\ dveh resnicah: konvencionalni resnici sveta \\ in temeljni resnici.
}

Nāgārjuna

\section{Uvod}

Filozofija indijskega budizma postaja $\mathrm{v}$ akademskih krogih predmet vse bolj živahnega proučevanja. Čeprav se največ pozornosti posveča zlasti začetkom budizma, tj. »hinajanskim« oz. abhidharma šolam ${ }^{1}$, ter zgodnji mahajani ${ }^{2}$, kamor

\footnotetext{
${ }^{1}$ Zgodnjebudistični sveti spisi so bili razdeljeni v »tri košare« (tri-pitaka): vinaya-pițako, zbirko pravil in navodil, povezanih z meniškim življenjem; sutra-pițako, ki je vsebovala splošne Budove govore, in abhidharma-pitako, zbirko del, ki so predstavljale sistematično razlago Budovega nauka (Dharme). Domneva se, da so različne »smeri« v zgodnjem budizmu imele vsaka svojo različico abhidharme, čeprav sta se v celoti ohranili le zbirki dveh »šol «: sarvāstivāde in sthaviravāde (theravāde) (King 1999, 83-84). V pričujočem kontekstu izraz abhidharma označuje vse zgodnje budistične šole (kot alternativa za slabšalni izraz »hinajana«; gl. tudi naslednjo opombo).

${ }^{2}$ Večkrat slišimo, da obstajata v budizmu dve tradiciji: mali voz (hinayana) in veliki voz (mahāyāna). Primož Pečenko takole opiše razliko med njima: »Š̆ole hinnayāna (tako so šole zgodnjega budizma imenovali predstavniki 'velikega voza') so učile, da je Buda navaden človek, ki se je z vztrajnimi meditativnimi napori duhovno tako razvil, da se je osvobodil vseh vezi pojavnega sveta (saṃsāra) in dosegel popolno ugasnitev sebičnih želja, jeze in nevednosti (nibbāna). Po njegovi smrti je ostal nauk (dharma), ki naj bi bil vodilo za vsakogar, ki si želi doseči popolno svobodo. Vsakdo se lahko osvobodi le sam, Buda je samo pokazal pot s svojim zgledom [...] V šolah mahāyāne pa so menili, da je bil Siddhartha Gotama, ki je dosegel razsvetljenje in postal Buda, manifestacija višjega duhovnega principa, ki je večen in onkraj pojavnega sveta. [...] Buda je sčasoma postal nekakšno božanstvo. Mahāyāna je učila, da se ljudje osvobodijo saṃsāre tudi s pomočjo nesebične ljubezni in sočutja (karun̄a), ki ga nebeški bude pošljejo v svet. Obstajajo bitja, pravi mahāyanāa, ki iščejo razsvetljenje (bodhisattva) in so se obvezala, da bodo poleg samih sebe osvobodila ves svet." (Pečenko 1990, 15-16) Več sodobnih avtorjev opozarja, da je takšna delitev neustrezna in zavajajoča. King denimo izpostavlja, da je izraz »hinajana« slabšalen in bi ga zato veljalo nadomestiti s kakim bolj nevtralnim izrazom (sam uporablja mainstream in abhidharma budizem), in nadaljuje, da se je mahajana razvila bolj kot »duhovna in filozofska usmeritev, ne pa kot neka specifična šola« (ni bila ena od 18 tradicionalnih budističnih šol). Ker je šlo torej bolj za »nekakšno transformativno usmeritev in ne za dobro opredeljeno sektaško gibanje«, pri čemer so nestrinjanja bila velikokrat vezana na praktična (»ortopraksija $\ll$ ) in ne na doktrinalna vprašanja (»ortodoksija«), spogledovanje z mahajano ni nujno vplivalo na posameznikovo pripadnost neki ločini (King 1999, 85-86). V
} 
se tradicionalno uvrščata madhyamaka (Nāgārjuna) in yogācāra (Asañga, Vashubandu), pa je vse več zanimanja tudi za logično-epistemološko šolo, katere najprominentnejša predstavnika sta Dignāga (5.-6. stol.) in Dharmakīrti (7. stol.). ${ }^{3}$ Čeprav je k temu, da sta budistična logika in epistemologija vstopili v horizont »zahodne« akademske sfere, pomembno prispevalo več avtorjev, pa lahko največ zaslug za pionirsko delo na tem področju zagotovo pripišemo $F$. Th. Stcherbatskyju, čigar poglobljena študija Budistična logika $\mathrm{v}$ dveh delih je številnim raziskovalcem služila in še dandanes služi kot odskočna deska za nadaljnje analize omenjenega področja.

V tem naraščajočem zanimanju za zgodnji indijski budizem pa se je v zadnjih desetletjih prejšnjega stoletja pojavilo več avtorjev, ki so postavili pod vprašaj nekatera temeljna prepričanja svojih predhodnikov, zlasti njihove poglede na vprašanje o kontinuiranosti oziroma prelomu $\mathrm{v}$ razvoju budistične misli $\mathrm{v}$ Indiji. Starejša generacija je namreč razvoj budistične filozofije prikazovala izrazito dialektično - kot niz tez in antitez -, pri čemer naj bi nastanku novih gibanj in šol botrovalo izrazito nestrinjanje in korenit prelom s starejšimi miselnimi tokovi. Mlajša generacija temu oporeka in izpostavlja, da temeljito proučevanje virov pokaže bistveno bolj kompleksno sliko: do razpada na različne šole naj bi prišlo veliko kasneje, kot se je sprva mislilo, obenem pa naj bi si bile te šole (vsaj prvotno) v marsičem precej podobne.

$\mathrm{V}$ pričujočem članku bomo $\mathrm{v}$ luči teh novih spoznanj skušali prevetriti nekatera vprašanja znotraj budistične logično-epistemološke šole, zlasti t.i. teorijo dveh resnic (»konvencionalno« in »temeljno« resnico), in skušali s pomočjo izsledkov analize pokazati, da je logično-epistemološki sistem Dignāge in Dharmakīrtija ${ }^{4}$ bistveno bolj povezan s predhodnimi miselnimi tokovi, kot so to

nadaljevanju članka bomo videli, da se sodobnejši avtorji nagibajo k prepričanju, da so ostre razlike med starejšim budizmom in mahajano kasnejšega datuma in da sta bili obe gibanji sprva bistveno bolj prepleteni, kot se je domnevalo.

${ }_{3}^{3}$ Čeprav budistično logično-epistemološko šolo večkrat prištevajo $\mathrm{k}$ yogācāri ali sautrāntiki, pa Hayes odločno svari pred tem, da bi »budistične epistemologe, zlasti Dignāgo, poistovetili s sautrāntiko ali katerokoli drugo ločino v budistični skupnosti«, saj se v svojih delih (povečini) niso ukvarjali z doktrinalnimi vprašanji, ki so razdeljevala budistične šole, temveč so se osredotočali skorajda izključno na epistemološke vsebine (Hayes 1988, 17). Morda bi bila z vidika določanja pripadnosti različnim ločinam še najustreznejša Kingova opredelitev, ki Dignāgo in Dharmakītija glede njune splošne filozofske orientacije uvršča v yogācāro, a pri tem poudarja, da »njuna dela pogosto zagovarjajo minimalistično abhidharma držo, utemeljeno na ohlapnih načelih sautrāntike« (King 1999, 102).

${ }^{4} \mathrm{~V}$ pričujočem članku bomo Dignāga-Dharmakīrtijev model obravnavali kot uniformen logičnoepistemološki sistem, čeprav med avtorjema obstaja precej razlik (za podrobnejši opis glej Hayes, 
domnevali Stcherbatsky in starejša generacija strokovnjakov, ter da je za pravilno razumevanje njegovega izvora, namena in strukture potrebno omenjeni sistem umestiti $\mathrm{v}$ širši kontekst budistične teorije in prakse.

Članek se deli na štiri dele. V prvem delu si bomo ogledali zgoraj omenjeni spor med starejšo in mlajšo generacijo strokovnjakov ter pokazali, da je bilo prvotno prepričanje, da gre $\mathrm{v}$ razvoju budistične filozofske misli za serijo diskretnih faz, napačno ali vsaj pretirano. Drugi del bo posvečen kratkemu pretresu razvoja budistične teorije dveh resnic, in sicer od zgodnjega (abhidharma) budizma do madhyamake (Nagarjuna) in yogācāre (Vashubandu), nato pa si bomo v tretjem delu ogledali še teorijo dveh resnic v epistemološkem sistemu Dignāge in Dharmakīrtija. V četrtem delu bomo skušali pokazati, da lahko strukturo in namen omenjenega sistema pravilno razumemo samo $\mathrm{v}$ okviru širše budistične teorije in prakse, katerih glavni namen je pokazati pot do nirvāne. Po naši tezi so logično-epistemološki razmisleki v budizmu neločljivo povezani z duhovno potjo, katere glavni namen je, da posamezniku pomaga, da se osvobodi vseh vezi pojavnega sveta, kar je $\mathrm{v}$ korenitem nasprotju $\mathrm{s}$ prepričanji marsikaterega starejšega avtorja.

\section{$2 \quad$ Prelom ali kontinuiteta?}

F. Th. Stcherbatsky deli zgodovino indijskega budizma na tri obdobja, na t.i. »tri obrate kolesja Dharme «", pri čemer umesti budistično logično-epistemološko šolo v tretjo, torej zaključno epoho. Prvo obdobje (5. stol. p.n.št.-1. stol. n.št.) je obdobje zgodnjega (abhidharma) budizma, za katerega je značilna »zelo natančna razčlenitev človekove osebnosti v prvine, iz katerih je sestavljena«. Glavni namen te analize je bil potrditi temeljni budistični nauk o neobstoju jaza, duše oz. sebstva

1988, 14-16), ki pa za našo razpravo niso bistvene. Specifična prispevka avtorjev bomo ločili le v zadnjem razdelku, kjer se bomo pritaknili razlik pri vprašanju odzadnjega motiva za ukvarjanje $\mathrm{z}$ logično-epistemološkimi vprašanji, ki so zelo pomembne pri poskusu umeščanja logike in epistemologije v širši budistični kontekst.

${ }^{5}$ V budizmu ima beseda dharma dva pomena: po eni strani se nanaša na »Budov zakon« ali »nauk« oz. - v širšem pomenu - na »pravičnost, krepost ali religijo«; po drugi strani pa označuje »pojave, obravnavane skupaj s pripadajočimi zavestnimi stanji« oziroma temeljne prvine, iz katerih je sestavljen pojavni svet (»pojavne atome«) (Eliot 2010, 123). Čeprav je pomen velikokrat razviden iz konteksta, bom za večjo preglednost - razen v navedkih, kjer bom ohranjal izvorno obliko - vse primere, kjer je beseda rabljena v prvem pomenu, pisal z veliko, ostale pa z malo. 
(nauk o ne-jazu ali anattā-vāda) ${ }^{6}$, v skladu s katerim to, kar v običajnem govoru imenujemo »jaz« oziroma »sebstvo«, ni nič drugega kot »konglomerat nenehno spreminjajočih se prvin« in ne vsebuje »nobene trajne substance«. Na podoben način je bil tudi zunanji svet, kot se kaže našim čutom, ontološko razčlenjen v nestalne in vedno spreminjajoče se prvine (dharme). Nenehni tok teh prvin pa ni naključen, temveč ga usmerjajo vzročni zakoni (nauk o soodvisnem nastajanju): »Vsaka prvina, pa čeprav se pojavi le za trenutek, je nastala 'v odvisnosti od drugih prvin'.« Za prvo obdobje indijskega budizma je po Scherbatskyju torej značilen pluralistični realizem:

Analiza zgodnjega budizma je potemtakem razkrila svet, ki sestoji iz toka nepreštevnih posamičnosti, ki po eni strani sestoji iz tega, kar vidimo, slišimo, vohamo, okušamo in otipljemo, po drugi strani pa iz preprostega zavedanja, povezanega $\mathrm{z}$ občutki, idejami, namerami (najsi dobrimi ali slabimi). $\mathrm{V}$ tem svetu pa ne najdemo nobene duše, boga ali materije - popolnoma ničesar trajnega in substancialnega. ${ }^{7}$ (Stcherbatsky 1962, 3)

V prvem stoletju našega štetja pride $\mathrm{v}$ budistični filozofiji do »korenite spremembe«, saj se zgodi ontološki premik od »radikalnega pluralizma« k »radikalnemu monizmu«. Za drugo obdobje indijskega budizma (1.-5. stol. n.št.), ki ga Stcherbatsky enači z madhyamako, je značilna »ideja o resničnem, pristnem, poslednjem obstoju oz. poslednji realnosti, realnosti, prosti vseh razmerij, realnosti sami po sebi, tj. neodvisni, neodnosni realnosti«. Ker so bile v zgodnjem budizmu vse fizične in duševne prvine medsebojno vzročno pogojene in potemtakem odvisne ena od druge, v zadnji instanci niso mogle veljati za resnične. Nova budistična miselnost je zato poslednjo realnost pripisovala samo »celoti teh prvin, vesolju kot takemu ${ }^{8}$, pojmovanemu kot Enost, kot edinstvena resnična substanca « (Stcherbatsky 1962, 9). Če so bile v prvem obdobju temeljne resničnosti oropane vse trajne substance (materija, duša itd.), je v drugem obdobju ista usoda doletela tudi vse psihofizične prvine (dharme): vsi elementarni podatki, $\mathrm{v}$ katere smo lahko razčlenili vsakdanji obstoj, so se izkazali za »relativne in posledično neresnične«. Glavni razlog za nerealnost prvin pa je bila njihova medsebojna vzročna povezanost:

\footnotetext{
${ }^{6}$ Nauk o ne-jazu je »najznačilnejša lastnost budistične misli in predstavlja izhodiščno točko vseh filozofskih šol budizma v Indiji . Po tem nauku »poleg nenehno spreminjajočega se toka dogodkov, ki tvorijo kompleks duh-telo, ne obstaja še nek àtman ali substancialni jaz«, kar je v očitnem nasprotju $\mathrm{z}$ »brahmanskimi pojmovanji o substancialnem jazu«, tj. o obstoju »nesnovne entitete, ki je transmigrirala iz enega življenja v drugo« (King 1999, 78).

${ }^{7}$ Vsi citati so moj prevod.

${ }^{8}$ Moj poudarek.
} 
Če so v primitivnem budizmu vse prvine medsebojno povezane in resnične, pa so te prvine $\mathrm{v}$ novem budizmu - v skladu z novo opredelitvijo resničnosti neresnične ravno zato, ker so medsebojno povezane. (Stcherbatsky 1962, 9)

Vendar pa novi budizem empiričnemu svetu ni odrekel resničnosti $v$ celoti, temveč je le trdil, da empirična resničnost ni poslednja resničnost: »Obstajata torej dve resničnosti, ena na površju in druga pod njim. Ena je navidezna, druga spet temeljna resničnost.« Ta teorija o dveh resnicah naj bi presegla klasični budistični nauk o štirih resnicah ${ }^{9}$, pri tem pa je pomembno poudariti, da poslednje resničnosti ni mogoče spoznati $\mathrm{z}$ »metodami in rezultati diskurzivnega mišljenja«: »Zato so vsa logika kot tudi vsi konstrukti zgodnjega budizma [...] odločno proglašeni za zmotne in protislovne konstrukte. Edini vir prave vednosti sta mistična intuicija svetnikov in razodetje novih (mahajanskih, op. av.) svetih spisov, katerih poglavitna tema je monistično razumevanje vesolja.« Takšno »neusmiljeno zavračanje vsakršne logike« in »povzdigovanje misticizma ter razodetja« naj bi bila še ena specifična lastnost novega budizma.

Za tretje obdobje razvoja budistične misli v Indiji (5.-10 stol. n. št.), ki pri Stcherbatskyju sovpada z yogācāro, so značilne nadaljnje pomembne spremembe. Prvič, prišlo je do vnovičnega zanimanja za logiko, ki proti koncu obdobja "preseže vso nekdanje teoretično delo budizma«. Drugič in $\mathrm{v}$ nasprotju $\mathrm{z}$ radikalnim skepticizmom drugega obdobja, introspekcija postane veljavni vir védenja, kajti »če zanikamo introspekcijo, zanikamo tudi samo zavest, s čimer celotno vesolje obsodimo na stanje absolutne slepote«. Tretjič, čeprav je za novo smer budizma značilno odklanjanje radikalnega skepticizma madhyamake, pa ohrani skeptično držo do obstoja zunanjega sveta: budizem postane idealističen sistem, ki trdi, da je »vse, kar obstaja, duševne narave in da naše ideje nimajo nobene opore v zunanji resničnosti«. Če so bile v prejšnjem obdobju neresnične vse ideje, saj so bile relativne, pa v yogācāri obstajajo zgolj in samo ideje. Niso pa bile vse ideje enako resnične - podobno kot $\mathrm{v}$ madhyamaki najdemo namreč tudi $\mathrm{v}$ yogācāri delitev na dve sferi: relativno in absolutno.

\footnotetext{
${ }^{9}$ Gre za dobro znane štiri plemenite resnice, ki jih je Buda razodel svojim učencem v slavni prvi pridigi pri Benaresu: 1. Resnica o neprijetnosti bivanja: »Rojstvo, starost, bolezen in smrt [kot nepogrešljivi deli življenja] so neprijetni (dukkha).«; 2. Resnica o izvoru neprijetnosti: »Izvor neprijetnosti so želje $(t r s ̦ n \bar{a})$.«; 3. Resnica o prenehanju neprijetnosti: »Obstaja stanje, v katerem ni trpljenja, in to stanje se imenuje nirvāṇa.«; 4. Resnica, ki vodi k prenehanju neprijetnosti: »Nirvāṇo dosežemo tako, da sledimo srednji poti med vsemi skrajnostmi. Ta pot ima osem korakov in vključuje razvoj (1) pravilnega razumevanja, (2) pravilnega mišljenja, (3) pravilnega govorjenja, (4) pravilnega delovanja, (5) pravilnega načina življenja, (6) pravilne vztrajnosti, (7) pravilne pozornosti, (8) pravilne zbranosti« (King 1999, 76; Pečenko 1990, 23-30).
} 
Prikazano Stcherbatskyjevo členitev so kasneje privzeli številni avtorji (S. Mookerjee, D.N. Shastri, T.R.V. Murti, R.R. Dravid itd.; njen odmev najdemo tudi v našem prostoru, gl. npr. Ule 2004, 19-21) in je postala izhodiščna točka »uveljavljene ortodoksije« (Harris 1991, 68). Chatterjee jo v strnjeni obliki prikaže takole:

Budizem torej ni en sistem, ampak matrica sistemov, ki zajema tri vélike filozofije in njihove prirastke, namreč realizem, kriticizem in idealizem. (Chatterjee v Kalupahana 1987, 4; moj poudarek)

Upravičenost prikazane tridelne členitve njeni zagovorniki utemeljujejo med drugim s sklicevanjem na Saṃdhinirmocanasūtro ali Sutro, ki razveže vozle (pribl. 3. stol. $)^{10}$, v kateri se prvikrat omenjajo trije obrati koleslja Dharme (King 1999, 96):

Najprej je Gospod v Jelenjem parku v Varanasiju pognal kolo Dharme v gibanje za zagovornike voza učencev (śrāvakayāna), in sicer v obliki nauka o štirih plemenitih resnicah [...] Ampak to gibanje je bilo preseženo, vzbudilo je kritiko, vsebovalo je implicitni pomen (neyārtha) in postalo predmet spora [...] Posledica tega je bila, da je Gospod začel učiti, da so vsi pojavi brez bistvene narave, da niso ne ustvarjeni ne uničeni, izvorno pomirjeni in po naravi v stanju nirvāṇe. Ta drugi koleselj Dharme je pognal v gibanje za zagovornike mahāyāne, in sicer v obliki naukov o praznini [...] Na koncu pa je Gospod učil, da so vse stvari brez bistvene narave [...] To tretje kolo Dharme, ki je brezhibno podano, je pognal v gibanje za zagovornike vseh vozov. Ta poslednji obrat je nepresežen, ne vzbuja kritike, vsebuje eksplicitni pomen (nitārtha) in ni predmet spora. (Harris 1991, 70)

Harris izpostavi, da natančen pomen navedenega odlomka ni povsem jasen: »Čeprav je precej očitno, na kaj se nanaša prvi obrat koleslja Dharme, saj gre za Budovo prvo pridigo o štirih plemenitih resnicah, pa je manj jasno, kako naj interpretiramo drugi in tretji obrat.« (Harris 1991, 70) To vprašanje je še vedno »predmet precejšnjega spora«, vendar Harris poudari, da »mu ni uspelo najti enega samega indijskega budističnega avtorja, ki bi zadnja dva obrata povezoval s posamičnimi mahajanskimi šolami«. Pogosteje se namreč dogaja, da »avtorji te obrate povezujejo s posebnimi izseki iz mahajanske kanonične literature«, in vse kaže, da je »do pripisovanja različnih obratov koleslja Dharme različnim 'šolam' prišlo razmeroma pozno v budistični zgodovini«, morda celo istočasno s prenosom budizma v Tibet, to je približno v sedmem stoletju (Harris 1991, 71). Harris na

\footnotetext{
${ }^{10}$ Žal je izvirnik v sanskrtu izgubljen, tako da je na voljo samo še tibetanski prevod.
} 
podlagi analize različnih stopenj na duhovni poti pri Asañgi, Bhāvaviveki in Candrakīrtiju omenja tudi možnost, da $\mathrm{v}$ navedenem odlomku iz Saṃdhinirmocanasūtre sploh ne gre za »omembo šol in njihovih zaslug«, temveč za »posamične stopnje samouresničitve pri duhovni praksi« (Harris 1991, 77).

Natančnejši pregled zgodnjih mahajanskih besedil pa pokaže, da tako med abhidharma budizmom in mahajano na eni kot tudi med različnimi šolami znotraj mahajane na drugi strani ne zeva tako velik prepad, kot ga prikazujejo Stcherbatsky in njegovi nasledniki. Harris dokazuje, da proti splošno uveljavljenemu mnenju, po katerem naj bi Nāgārjuna (dozdevni začetnik madhyamake) $\mathrm{v}$ celoti prelomil s tradicijo starega budizma in ustanovil povsem neodvisno filozofsko šolo, pričata dva pomembna razloga: »Prvič, videti je, da se [Nāgārjuna] z odobravanjem sklicuje na nekatera zgodnja besedila, in drugič, med njegovimi stališči in stališči v zgodnjih besedilih obstaja velika skladnost.« (Harris 1991, 60). ${ }^{11}$ Nāgārjuna je zato prej kot revolucionarju podoben »branitelju pravega nauka«, nekomu, ki »skuša ortodoksijo ubraniti pred novimi in potencialno heretičnimi nauki« (Harris 1991, 60). Njegova kritika ni bila naperjena proti staremu budizmu kot takemu, temveč proti njegovim specifičnim podskupinam: proti pluralističnim dharma šolam, kot je bila sarvāstivāda, ki so trdile, da v zadnji instanci obstajajo samo dharme, dočim so ostale stvari zgrajene iz teh temeljnih gradnikov. Z Warderjevimi besedami:

Iz vsega tega je razvidno, da Nāgārjuna sprejema starodavno različico Tripitake, ki so jo verjetno vse budistične šole priznavale kot učenje Bude, napada pa to, kar pojmuje kot napačno interpretacijo tega učenja s strani sholastičnih tradicij. Poudarja, da v svojih delih le obnavlja izvorni pomen starih suter, in dokazuje, da novosti, ki so jih uvedle posamične šole, vodijo v protislovja in so v neskladju s tem, kar razume kot bistveni nauk, namreč teorijo o soodvisnem nastajanju. Tu je težko govoriti o kakršnemkoli prestopu v novo mahajana gibanje. (Warder v Harris 1991, 61)

Te ugotovitve pa ne veljajo samo za Nāgārjuno, temveč tudi za Asañgo in Vasubandhuja, dozdevna začetnika yogācāre: »[N]e Nāgārjuna ne Asañga ne Vasubandhu niso graditelji sistemov $\mathrm{v}$ splošno sprejetem pomenu te besede,

\footnotetext{
${ }^{11}$ Zavoljo prostorskih omejitev se v natančnejši prikaz te »skladnosti« na tem mestu ne moremo spuščati, zato bodi dovolj, če povemo, da se med drugim kaže v dejstvu, da najdemo »omembe praznine« in »zametke madhyamaka miselnosti« že v najzgodnejši budistični literaturi, kjer se »praznina« nanaša na nirvāno, pojmovano kot »stanje, v kateri pride do zloma subjektivnosti in objektivnosti«, kar ustreza Nāgārjunovi uporabi tega izraza (Harris 1991, 51). Gl. tudi naslednji razdelek za natančnejšo predstavitev Nāgārjunove pozicije.
} 
ampak so si zadali skupno nalogo, da tradicionalni budistični nauk preoblikujejo na tak način, da bo z njim možno reševati specifične probleme«. Omenjeni avtorji torej niso inovatorji, marveč »razlagalci, ki tradicionalni nauk prilagajajo potrebam specifičnih nalog, pri čemer glavnina nauka ostaja nespremenjena in onstran dvoma« (Harris 1991, 68). Razvoj indijskega mahajana budizma potemtakem ne sestoji iz »zaporedja ločenih in razhajajočih se šol; nasprotno, različni ključni avtorji so osvetlili temeljne nauke $\mathrm{z}$ različnih vidikov in $\mathrm{v}$ nesektaške namene« (Harris 1991, 73). Kot strnjeno pove Kalupahana: »Revolucije (re-volutions) potemtakem niso spremembe, kot jih običajno razumemo, ampak vrnitve (re-turnings) k izvornemu sporočilu.« (Kalupahana 1987, 5)

V luči pravkar povedanega je vprašljiva tudi Stcherbatskyjeva trditev, da se v ozadju interesa Dignāge in Dharmakīrtija ${ }^{12}$ za logično-epistemološka vprašanja skriva reakcija na »ekstremni skepticizem madhyamake«. Hayes zapiše, da »ne le, da v Dignāgovih eksplicitnih izjavah ni nobenih neposrednih dokazov, da bi slednji gojil negativno držo do madhyamake, ampak [...] lahko v Dinnnāgi vidimo celo naravni razvoj smernic, ki so prisotne tako v zgodnjem kanoničnem budizmu kot tudi v gibanju madhyamaka; skratka, nobenega razloga ni, da bi Dinnāgovo epistemologijo videli kot reakcijo na predhodno budistično gibanje« (Hayes 1989, 13). Hayes nadalje dokazuje, da se v budistični filozofiji - od samih začetkov pa do Nāgārjune in Vashubandhuja - prepletata dva miselna tokova (posebni obliki »skeptičnega racionalizma« in »nominalizma«) in da »oba tokova igrata ključno vlogo tudi v Dignāgovem [in Dharmakīrtijevem] sistemu«, kar dokazuje, da slednji ne predstavlja »radikalnega odklona« ne od zgodnjega ne od Madhyamaka budizma (Hayes 1989, 41).

Vidimo torej, da se je med novejšimi avtorji uveljavilo prepričanje, da je tripartitna shema indijskega budizma napačna ali vsaj nepopolna, in da se skozi celotno indijsko budistično filozofijo vije neka skupna miselna nit. Dela budističnih mislecev, kot sta Nāgārjuna in Vashubandhu, ki jih je starejša generacija strokovnjakov prikazovala kot nosilce $»$ kopernikanskih revolucij«, se po tej interpretaciji kažejo bolj kot »poskusi obnovitve Budovega nauka«, ne pa kot prelomi s prejšnjimi miselnimi tokovi (Kalupahana 1987, 5). Sama narava te kontinuiranosti $-\mathrm{s}$ čimer imam $\mathrm{v}$ mislih vprašanje, $\mathrm{v}$ kolikšni meri in $\mathrm{v}$ katerih ozirih so posamične »tradicije« indijskega budizma res soglasne - je za našo

\footnotetext{
${ }^{12}$ Stcherbatsky oba avtorja uvršča v yogācāro, čeprav je takšna kategorizacija problematična (gl. op. 3 zgoraj).
} 
razpravo drugotnega pomena; pomembno je predvsem, da se zavedamo, da je bila logično-epistemološka budistična šola, ki je glavni predmet naše razprave, vpeta $\mathrm{v}$ širši koncept budistične filozofije in je razvijala določene teme, prisotne $\mathrm{v}$ predhodni budistični misli, kar bo - kot bomo videli v zadnjem poglavju - igralo pomembno vlogo pri natančnejšem razumevanju narave in namena DignāgaDharmakīrtijevega modela.

\section{Teorija dveh resnic $\mathrm{v}$ budizmu}

Ena od tem, ki igra pomembno vlogo $\mathrm{v}$ opisanem modelu, je budistična teorija o dveh resnicah (konvencionalni in temeljni), katere razvoj si bomo na kratko ogledali v tem poglavju. ${ }^{13}$ Harris izpostavi, da v najzgodnejši budistični literaturi ne zasledimo eksplicitne omembe dveh resnic; nasprotno, najdemo le trditev, da je resnica »ena sama«: »Obstaja ena sama in edina resnica. Ker si ljudje glede tega niso na jasnem, trdijo, da je resnic več.« (Sutta Nipata, v Harris 1991, 84)

Vendar pa satye tukaj ne gre razumeti kot »ontološko enotnega absoluta«, kakršnega srečamo v Śañkarini advaita vedānti, temveč zgolj kot zahtevo, da "posamične trditve ne smejo biti medsebojno protislovne«, tj. »da vse kažejo v neko skupno splošno smer oziroma so medsebojno usklajene« (Harris 1991, 84), torej kot nekakšen osnovni pogoj za racionalnost diskurza. Čeprav teorija o dveh resnicah ni nikjer eksplicitno omenjena, pa je nedvomno implicitno prisotna:

Videti je, da v pālijskem kanonu med omenjenima resnicama ni jasne razlike, čeprav že samo dejstvo, da je Buda v vsakdanji govorici uporabljal osebne zaimke in govoril o osebah, medtem ko je v svojih bolj teoretičnih trenutkih trdil, da ne obstaja nek samostoječi jaz (sanskrt: anātman/pāli: anattā), priča o implicitni razliki med vsakdanjimi in teoretičnimi konteksti diskurza. (King $1999,83)^{14}$

\footnotetext{
${ }^{13}$ Tukaj bi veljalo izpostaviti, da sanskrtska beseda za resnico (satya) nima enoznačnega pomena, saj označuje tako »resnico« v klasičnem (zahodnem) pomenu - tj. resnico, ki se nanaša na »nosilce resnic« (stavke, propozicije oz. prepričanja, teorije ipd.) - kot tudi »resničnost«, »dejanskost« oziroma »obstoječe« (torej na spoznavne predmete) (The Cowherds 2011, 4-5). Določeni, zlasti kasnejši budistični avtorji tako poleg dveh resnic govorijo tudi o dveh resničnostih. Slovenskemu bralcu to razlikovanje morda ne bo tako zelo nenavadno, saj imata v slovenščini obe besedi skupni koren (podobno je z nemškim izrazom Wirklichkeit), kot denimo nekomu, ki živi v angleško govorečem okolju, kjer so stvari manj razvidne (truth in reality).

${ }^{14}$ Podobno misel najdemo pri Harrisu: $» \mathrm{~V}$ abhidharmi najdemo izraženo misel, da čeprav običajni ljudje lahko razumejo vsakdanjo govorico o osebah (puggala) itd. in v skladu z njo tudi uravnavajo
} 
V besedilih je torej prisotno razlikovanje med »običajnimi« izrazi, ki so resnični v »vsakdanjem《 življenju, in »teoretičnimi« (»temeljnimi«) izrazi, ki odražajo stvari »takšne, kakršne so«.

Poleg te implicitne razlike pa $\mathrm{v}$ zgodnji literaturi najdemo še en pomemben razloček, in sicer med dvema tipoma sūter: tistim z neposrednim (nīttatha) in tistim s posrednim pomenom (neyyattha). Vse kaže, da je bilo to razlikovanje izvorno prosto "vsakršnih vrednostnih oznak« in da je bil njegov glavni namen "pedagoške narave«: šlo naj bi le za to, da je »[e]na vrsta suter primernejša za osebe $\mathrm{z}$ določenimi značajskimi lastnostmi ali za osebe na določeni stopnji duhovnega razvoja, spet druga pa za koga drugega «(Harris 1991, 85).

Teorija o dveh resnicah se prvikrat eksplicitno omenja šele v pālijskih delih kasnejših komentatorjev in je najverjetneje nastala kot poskus »uskladitve dozdevno protislovnih izjav v svetih spisih, utemeljenih na njihovem pedagoškem namenu« (The Cowherds 2011, 5). Takšna sistematizacija »številnih dozdevno nasprotujočih si omemb resnice v naraščajočem oceanu doktrine« je privedla do spoja zgoraj omenjenih implicitnih omemb »običajnega« in »temeljnega« ter razlikovanja med suttrami s posrednim in neposrednim pomenom (The Cowherds 2011, 87). Stara dvojica nittatha/neyyattha tako dobi novo interpretacijo:

Sūtra oblike »O, menihi, obstaja en posameznik« itd. je sūtra s posrednim pomenom [...]. Čeprav namreč povsem budni tukaj pove: »O, menihi, obstaja ena oseba, « moramo do njenega pomena priti s sklepanjem, kajti z vidika temeljne resnice oseba ne obstaja... Sütra z neposrednim pomenom (bi morala imeti obliko) »to je nestalno, nezadovoljivo in brez duše« (Manorathapūrani v Harris 1991, 86).

Kasnejši komentatorji torej v pojmovno dvojico, ki je imela prvotno le pedagoško vlogo, vnesejo razliko v stopnji: sūtre z neposrednim pomenom izražajo temeljno resnico, medtem ko tiste $\mathrm{s}$ posrednim pomenom izražajo le običajno oziroma konvencionalno resnico.

Kljub počasni uveljavitvi tega dvoslojnega pojmovanja resnice pa je za abhidharma budizem značilna neka temeljna napetost glede vprašanja o naravi odnosa med obema resnicama, zlasti glede vprašanja o njuni povezavi z jezikom. $\mathrm{Na}$ eni strani srečamo stališče, ki so ga zastopale pluralistične struje (denimo, sarvāstivāda) in po katerem lahko z besedami izrazimo obe resnici, na drugi strani 
pa stališče, implicitno prisotno $\mathrm{v}$ nekaterih $s \bar{u} t r a h^{15}$, da lahko ubesedimo samo konvencionalno resnico, medtem ko je temeljna resnica neubesedljiva. Po prvi interpretaciji je razlika med konvencionalno in temeljno resnico podobna razliki med dvema jezikoma: izjave s posrednim pomenom vsebujejo običajne izraze, kot so stol, miza itd. (empirični predmeti), in je zato njihova resničnost omejena, izjave z neposrednim pomenom pa vsebujejo temeljne izraze, kot so zaznave itd. (dharme), in je njihova resničnost zato absolutna. Razlika med običajno in temeljno resnico potemtakem ni razlika med ubesedljivim in neubesedljivim (tako prvo kot drugo lahko izrazimo z besedami), temveč v tem, da terminološka shema, $\mathrm{s}$ katero je izražena temeljna resnica, bolje odslikava resničnost kot terminološka shema, povezana s konvencionalno resnico (Harris 1991, 92-97).

Po drugi interpretaciji pa lahko z besedami izrazimo le konvencionalno resnico, medtem ko je temeljna resnica $\mathrm{v}$ zadnji instanci neizrekljiva - jezik namreč zavoljo svoje osnovne strukture (dihotomna narava, substancializacija resničnosti itd.) ni primeren medij za artikulacijo absolutne resnice, ki je $\mathrm{v}$ domeni »razsvetljenih«. To lepo prikazuje podoba, da je Budov nauk kot splav, ki ga moramo odvreči, kadar pridemo na drugo stran reke - njegova učenja nimajo temeljnega pomena, saj je »Dharma v zadnji instanci neubesedljiva« (Harris 1991, 97). Največ, kar lahko dosežemo na ravni jezika, je, da pokažemo v smeri temeljne resnice: konvencionalna resnica je potemtakem podobna pregovornemu prstu, ki kaže na luno (temeljna resnica), ni pa luna sama.

$\mathrm{Na}$ to drugo interpretacijo, tj. na prepričanje, da je »[m]reža jezika [...] metasistem, ki je poveznjen čez svet, vendar ločen od njega« in zato »inherentno neustrezen pri razlagi stvari, kot so« (Harris 1991, 95), se je navezala tudi mahajanska tradicija. Čeprav prajñāpāramitā literatura ${ }^{16}$ vsebuje le »implicitne omembe konvencionalne in temeljne resnice«, pa najdemo »prvo natančno

15 V Cūla Mālunikyasutti Buda denimo noče odgovoriti na več filozofskih vprašanj (o končnosti/neskončnosti vesolja, istovetnosti duše in telesa ipd.), ker bi odgovori imeli »zavajajoče posledice«. V tej sūtri je poudarjeno, da se Buda želi »ogniti dogmatičnim ugibanjem«, saj tovrstne dejavnosti vse udeležence le zapletajo v »'mrežo' Brahme«, in Harris poudari, da to ne velja le za 14 tradicionalnih vprašanj, omenjenih v sūtri, temveč za vsa vprašanja oblike: »Ali je res, da [...]?« V Kaccāyanavādi najdemo omembo, da ne moremo oblikovati stavkov, ne da bi se pri tem naslanjali na izraza »obstaja«/»ne obstaja«: uporaba jezika nas nujno pahne v ta dva ekstrema. In ker Budovo stališče zavzema srednjo pot med njima, lahko sklepamo, »da je dharma $\mathrm{v}$ zadnji instanci neizrekljiva« (Harris 1991, 96-97).

${ }^{16}$ Gre za »zgodnje mahajanske svete tekste«, nastale okoli prvega stoletja našega štetja, v katerih so prvič (sicer nesistematično) predstavljene specifično mahajanske filozofske vsebine (prajñāpāramitā pomeni »izpopolnitev modrosti«) (King 1999, 91). 
obravnavo te specifične doktrine« pri Nāgārjuni (Harris 1991, 102-3). Za slednjega je temeljna resnica tesno povezana $\mathrm{z}$ njegovim razumevanjem "praznina« (śünyatā) in označuje razpad dihotomije med subjektom in objektom, zato je nujno neubesedljiva. Vendar pa se oba tipa resnice medsebojno ne izključujeta, saj »[a]bsolutne resnice ne moremo izraziti, ne da bi se zanašali na vsakdanjo prakso (tj. konvencionalno resnico)« (Mülamadhyamakakārikāa, xiii. 8, v Harris 1991, 112). Ne gre torej za ontološki dualizem dveh neodvisnih ontoloških domen, temveč za dve spoznavni drži do ene same resničnosti, značilni za »običajne ljudi« na eni in »razsvetljene osebe« na drugi strani. »Ubesedena Dharma « (konvencionalna resnica) vsebuje »zametek lastnega samopreseganja, saj nakazuje na temeljno resničnost stvari, ki je neizrekljiva« (Harris 1991, 114). ${ }^{17}$

Če je običajna resnica povezana in pogojena $\mathrm{z} » d$ delovanjem nerazsvetljenega razuma « in $» j o$ motivira nevednost $(\text { avidy } \bar{a})^{18}{ }^{1}$, pa je temeljna resnica stanje, $\mathrm{v}$ katerem »sta dihotomija (prapañca) in izdelovanje misli (vikalpa) zamrli«: poslednja resnica je »osvobojena dvojnosti, značilne za običajno resnico (samvv!ti)«, in »zato ne-dvojna (advaya)« (Harris 1991, 115). To se lepo sklada s pojmovanji, ki jih najdemo pri yogāāara avtorjih. Vashubandu denimo razlikuje med »popačeno« in »nepopačeno« obliko kognicije. Za prvo je značilno, da je vpeta $\mathrm{v}$ mrežo nevednosti, mnenj itd. in je zato njeno videnje sveta popačeno (konvencionalna resnica), medtem ko je druga prosta takšnih onesnaženj in zato vidi stvari takšne, kot so (temeljna resnica) (Hayes 1988, 94-95). Poleg tega se razumevanje dveh resnic pri Nāgārjuni ujema s pojmom treh narav v yogācāri ${ }^{19}$ : temeljna resnica sovpada $\mathrm{z}$ »dovršeno naravo«, konvencionalna resnica pa se deli na dva dela: povsem neresnični (domišljijski) del sovpada $\mathrm{z} »$ namišljeno naravo«,

\footnotetext{
${ }^{17}$ Kratek očrt Harrisove interpretacije Nāgārjune: »[N]erazsvetljeni duh z izdelovanjem misli (vikalpa) ustvarja napačne dihotomije (prapañca), kar privede do vere v obstoj sveta, sestavljenega iz gradnikov (dharma), ki posedujejo sebi lasten obstoj (svabhāva). Razsvetljeni duh pa je izpraznjen (śünya) takšnih pojmov in naloga nekoga, ki hodi po budistični poti, je, da skuša udejanjiti to razsvetljeno stanje. Zaključek poti sovpada s prebujenjem gnoze (prajñā), ki je ne-dvojna vednost (advayajñāna)«(Harris 1991, 124).

${ }^{18}$ Glej tudi naslednji razdelek.

${ }^{19}$ Gre za »tri ravni, vidike ali razsežnosti izkustva«: parikalpita svabhāva ali izdelana oz. namišljena domena izkustva, paratantra svabhāva ali pogojena domena izkustva in parinișpanna svabhāva ali izpopolnjena domena izkustva. »Izdelana narava« ponazarja »našo inherentno nagnjenost $\mathrm{k}$ 'popredmetenju' izkustva«, tj. »k pripisovanju 'neodvisnega obstoja' (svabhāva) vtisom, ki jih srečujemo v zaznavi«. »Odvisna narava« se nanaša na »to, kar dejansko obstaja«, tj. na »tok trenutnih dharm «, ki so medsebojno odvisne (vzročno povezane). Pri »izpopolnjeni naravi« pa gre za »enak vzročni tok zavestnih dogodkov, vendar brez napak in zmotnih pripisovanj, značilnih za parikalpita raven«: označuje »čisto zaznavo« oziroma to, da »vidimo stvari takšne, kot so«, »brez posredovanja pojmov«(King 1999, 98).
} 
tisti del, ki namiguje na poslednjo resnico (tj. vsebuje »zametek lastnega samopreseganja«), pa s »pogojeno naravo« (Hayes 1988, 123-4). Vidimo, da ima "pogojena narava« dva vidika: »Ker imamo zaradi domišljije napačen pogled na stvari, kar vodi v trpljenje, je rečeno, da paratanra [»pogojena narava «] prispeva $\mathrm{k}$ trpljenju. Če pa si jo ogledamo v njenem drugem vidiku, neomadeževano $\mathrm{z}$ zgornjimi procesi, je paratantra istovetna $\mathrm{z}$ dovršeno naravo« (Hayes 1988, 126).

\section{Dve resnici pri Dignāgi in Dharmakīrtiju}

Takšna je bila torej intelektualna klima znotraj budistične tradicije, v kateri je nastajal Dignāgov in Dharmakīrtijev logično-epistemološki model. ${ }^{20}$ Zato ne preseneča, če na dvojnost naletimo že v sami zasnovi njunega sistema:

Zaznava in sklepanje sta edina načina, da pridemo do vednosti. Obstajata le ta dva načina, saj lahko spoznamo le dva atributa; ne obstaja namreč noben drugi spoznavni predmet, kot so posamičnosti in splošnosti. Pokazal bom, da je predmet zaznave posamični vidik, predmet mišljenja pa splošni vidik. (Pramāṇasamuccaya $\vee$ Hayes 1988, 133)

Obstajata le dva spoznavna vira, in sicer neposredni (zaznava) in posredni (mišljenje). Ker pa je pravo spoznanje le »novo spoznanje«, - »spoznanje doslej še nespoznanega predmeta« oziroma »prvi spoznavni trenutek« - je spoznavni vir v strogem pomenu samo eden, in sicer zaznava. »Trajno spoznanje« oz. »mišljenje« namreč ni spoznanje, temveč "pre-poznanje« (kognicija versus re-kognicija): »Spoznavni element našega duha je omejen na tisti trenutek, ko se prvič zavemo prisotnosti nekega predmeta. Temu sledi sintetično dejanje razuma, ki proizvede obliko ali podobo predmeta.« Čuti, v katerih se vrši zaznava, in razum, v katerem poteka mišljenje, sta torej dva različna spoznavna instrumenta: »Čuti sprejemajo, razum pa izdeluje« (Stcherbatsky 1962, 64-65; moji poudarki).

V skladu s povedanim sledi, da obstajata »dva tipa stvari, ki so lahko predmet našega zavedanja《: posamičnosti oz. »[stvari], ki so neposredno prisotne v enem od čutov« in splošnosti oz. 》[stvari], ki sicer niso prisotne v naših čutih, a vseeno vstopajo v našo zavest«. Takoj ko začnemo »specifične atribute«, ki so na razpolago našim čutom, »sintetizirati $\mathrm{v}$ 'predmete' ali 'posamezne entitete' $\mathrm{z}$ več

\footnotetext{
${ }^{20} \mathrm{~V}$ tem modelu sta logika in epistemologija nepogrešljivo povezani: poleg »nauka o silogističnih oblikah«, vsebuje namreč tudi »teorijo čiste zaznave«, »teorijo o zanesljivosti naše vednosti in o resničnosti zunanjega sveta, kot ga spoznavamo s pomočjo zaznav in podob« (Stcherbatsky 1962, 1).
} 
lastnostmi« oz. jih začnemo »prepoznavati kot posamezne primerke nekega razreda«, je že na delu »spoznavna dejavnost, ki se razlikuje od čiste zaznave«. Trenutek, v katerem se konča zaznava in začne mišljenje, nastopi takrat, kadar neki stvari pripišemo ime, rod, kakovost ipd. (Hayes 1988, 133-4)

Dignāga pravi, da je zaznava »brez strukture«, pri čemer »struktura« pomeni ravno »pripis imena, splošnosti ipd.« Posamičnosti, ki so predmet zaznave, so potemtakem gole danosti, proste vseh »interpretativnih procesov in organiziranja podatkov v klasifikacijske sheme, osnovane na preteklih izkušnjah, brez katerih ni razumevanja ali jezika«. Ko te neposredne danosti vstopijo v čute, jim »razum pripiše neko ime, kar pomeni, da jih razporedi v razrede«, s tem pa izstopimo iz domene neposredno danega in vstopimo v sfero »skupnih atributov«, ki ne pripadajo »le stvarem, ki jih neposredno zaznavajo čuti«, ampak tudi »predmetom, ki se jih spomnimo v preteklosti, pričakujemo v prihodnosti ali na kak drug način niso prisotni v čutih«. Mišljenje, presojanje oz. sklepanje je potemtakem »kompleksna spoznavna dejavnost«, ki ima za svoj predmet »skupni ali splošni atribut tega, kar ni prisotno v čutih«, in je zato radikalno drugačno od »zaznave«, ki je »preprosto kognitivno dejanje, ki se ukvarja samo s tem, kar je neposredno dano« (Hayes 1988, 135).

Ker so predmet zaznave neposredne danosti, tj. stvari, kakor se nam kažejo tukaj-in-zdaj, je vsaka nova zaznava »edinstvena«: ne moremo je primerjati z nobenim drugim predmetom, kar pomeni, da je »neupodobljiva in neizrekljiva«. Predmet mišljenja pa je »izdelana enotnost« oz. »sintetična enotnost, ki zajema kategorije prostora, časa in kakovosti« in je »upodobljena in imenovana« (Stcherbatsky 1962, 70-71). Vidimo torej, da obstajata dve resničnosti: temeljna (neposredna), ki sestoji iz čistih posamičnosti oz. golih danosti in je brez vseh določljivih atributov, torej neupodobljiva in neubesedljiva, ter pogojena (posredna) resničnost, ki sestoji iz popredmetenih podob, poseduje številne določljive atribute (prostor, čas, čutne kakovosti), je upodobljena in ubesedena.

Z zaznavo oz. neposrednim spoznavnim virom spoznavamo temeljno resnico, ki kaže stvari takšne, kot so (temeljna resničnost): neupodobljivi in neizrekljivi tukaj-in-zdaj; z razumom oz. posrednim spoznavnim virom pa spoznavamo konvencionalno resnico, ki kaže duševne konstrukte: posamičnosti, obdelane $\mathrm{z}$ razumskimi kategorijami. Konvencionalna resnica torej ni čista izmišljotina, saj deleži na temeljni resnici (je odvisna od nje), hkrati pa je le deloma resnična, saj so danosti »popačene« $\mathrm{z}$ razumskimi kategorijami. 


\section{Epistemologija in logika kot nepogrešljiva dela budistične prakse}

V zadnjem razdelku bomo skušali Dignāgov in Dharmakīrtijev logičnoepistemološki model umestiti v kontekst širše budistične filozofije in prakse ter na podlagi doslej prehojene poti pokazati, da so stališča, ki imenovani sistem strogo ločijo od predhodne budistične tradicije, napačna. Čeprav ni splošnega konsenza o vlogi, ki naj bi jo logika in epistemologija igrali v budističnem sistemu, pa je med zgodnjimi avtorji prisotna tendenca, da ju obravnavajo kot nekaj, kar je drugotnega pomena: kot razumsko dejavnost, ki ni neposredno povezana $\mathrm{s}$ temeljno budistično teorijo in prakso (doseganje nirvāṇe) in/ali je nastala za reševanje nekega specifičnega problema. Stcherbatsky denimo v skladu s svojim »dialektičnim« pojmovanjem zgodovine budistične misli, opisanem v drugem razdelku, zastopa mnenje, da budistična logika in epistemologija nista imeli »nobene posebne povezave $\mathrm{z}$ budizmom kot religijo, tj. kot naukom o poti, ki vodi do odrešitve« (Stcherbatsky 1962, 2) in da je bil glavni cilj proučevanja logike in epistemologije »nadomestiti starodavno filozofijo zgodnjega budizma«. (Stcherbatsky 1962, 37) Conze je še bolj radikalen in trdi, da so logičnoepistemološka vprašanja zanimala le peščico budistov, pri drugih pa niso »dobila podpore«, saj so bila del »popolnoma profane vede«. Ker je bila logika »v nasprotju z budističnim duhom«, je bila tolerirana le kot »manifestacija 'uporabne veščine'« in proučevana izključno $\mathrm{z}$ namenom »premagovanja zagovornikov nasprotnih stališč (Conze v Hayes 1988, 4). Podobne misli najdemo tudi pri drugih avtorjih, ki v budistični logiki vidijo pomagalo $\mathrm{v}$ metafizičnih sporih $\mathrm{z}$ ortodoksnimi indijskimi šolami, naslednji korak v lingvističnih proučevanjih ipd. (za natančnejši prikaz gl. Hayes 1988, 3-33).

Naš namen bo dokazati, da je takšna delitev napačna in da je - kot trdi Hayes glavni motiv v ozadju budistične logike »pot do nirvāne«. Preden utemeljimo to misel, pa moramo nekaj kratkih besed nameniti razlikam $\mathrm{v}$ motivaciji med Dignāgo in Dharmakīrtijem. Če smo v dosedanji predstavitvi omenjena avtorja obravnavali kot enoto in pri tem namenoma prezrli nekatera (za našo razpravo) manj pomembna razhajanja med njima, pa to pri vprašanju motiva oziroma namere v ozadju njunih prizadevanj več ni mogoče. Ker sta avtorja delovala v različnih časih, je bil različen tudi motiv za nastanek njunih del: če je bila glavna motivacija Dignāge soteriološke narave, tj. vzpostavitev logično-epistemološkega sistema, ki naj posamezniku pomaga na duhovni poti, pa je bil glavni namen Dharmakīrtijevega dela apologetski, tj. ubraniti budistični nauk pred njegovimi (zunanjimi) kritiki in pokazati »resničnost budistične pozicije s pomočjo 
racionalne argumentacije« (Hayes 1988, 33). Pri tem pa je pomembno izpostaviti, da Dignāga ni želel le »argumentirano pokazati, kako lahko dosežemo nirvāṇo«, temveč »moramo njegova dela o logiki in epistemologiji razumeti kot del njegove lastne meditativne prakse, usmerjene k neposrednemu doseganju nirvāne» (Hayes 1988, 33). Pri razliki v odzadnjih motivih Dharmakīrtija in Dignāge bi lahko govorili tudi o razliki med teorijo in prakso: če je glavni namen Dharmakītija predstaviti racionalno podlago budističnega sistema, je namreč primarni cilj Dignāge pomagati v prizadevanjih pri doseganju nirvāṇe. Sedaj si pa oglejmo, v kakšnem smislu bi logika in epistemologija lahko prispevali k zadanemu cilju.

Kot izpostavlja Hayes, je bil glavni namen budistične filozofije v svetih spisih ponuditi teoretično osnovo za budistično prakso, glavni namen budistične prakse pa je bil doseganje nirvāṇe. Budistična filozofija potemtakem ni bila sama sebi namen, temveč je bila $v$ njej že od samega začetka prisotna izrazito praktična komponenta: pomoč pri iskanju in doseganju »osvoboditve« (nirvāṇe). O kakšni »osvoboditvi« je govora? Po budistični tradiciji naj bi šlo za osvoboditev od različnih oblik »trpljenja in neprijetnosti«, pri katerih igra glavno vlogo »množica zmot v razumevanju, ki so znane pod skupnim imenom avijjā ali nevednost« (Hayes 1988, 42). Nevednost je $\mathrm{v}$ budizmu opredeljena kot »nepravilno razumevanje pojavnega sveta«, ki »povzroča navezanost na pretekle izkušnje« in je »izvor celotnega sveta nasprotij in neprijetnosti [dihotomnega sveta, razcepljenega na subjektivni in objektivni del], ki se hkrati z njim pojavljajo« (Pečenko 1990, 32). Premagamo jo lahko le z »modrostjo (pañña) «, s katero človek »celostno doživlja svet« in se pomakne »onstran nasprotij, ki izvirajo iz jaza«: »Ko je zaznava čista, ko ni obarvana z željami (lobha), jezo (dosa) in zmotnim mišljenjem (moha) [ki izvirajo iz nevednosti], se pojavi celostno, tj. neegoistično razumevanje sveta, ki se avtomatično manifestira kot neskončna in nesebična ljubezen, brezželjnost, prijateljstvo in modrost« (Hayes 1988, 45).

Budizem potemtakem ni le miselni sistem, temveč - in predvsem - način življenja, katerega glavni cilj je osvoboditev od vseh neprijetnosti, ki izvirajo iz nevednosti. To je zlasti razvidno, če si ogledamo »četrto plemenito resnico« oz. »resnico o poti, ki vodi k prenehanju neprijetnosti [trpljenja]«, pri kateri gre za »opis praktične metode, ki pripelje do najgloblje intuitivne izkušnje prvih treh resnic ${ }^{21}$ : $\gg$ Kdor teorijo (prve tri resnice) oživlja in poglablja s konkretno

\footnotetext{
${ }^{21}$ Ta praktična metoda pa sestoji iz osmih členov, ki se delijo v tri dele: modrost (prajñā), vrline (ś̉a) in zbranost (samādhi). Gl. tudi op. 7 zgoraj.
} 
meditativno prakso (četrta resnica), razvija in poglablja intuitivno dojemanje sveta«. Pojmovno mišljenje je le začetni korak na tej poti: pomemben, a vendarle nezadosten korak, ki ne pripelje do končne odrešitve, če ni podkrepljen z ustrezno prakso (meditacija). Šele s pomočjo slednje lahko namreč razvijemo »izkustveno modrost, ki je dosti globlja od intelektualnega razumevanja«: »Do take modrosti ne pripelje razmišljanje, ki je zgolj konceptualno, kakor tudi nobeno 'teoretično' znanje, saj gre tu za neposredno, globoko in intuitivno raven dojemanja, ki je onkraj misli, pojmov, idej« (Hayes 1988, 29, moji poudarki). Temeljna resnica budizma je $\mathrm{v}$ zadnji instanci neubesedljiva ravno zato, ker preči kategorije razuma in jezika: je nekaj, kar je nerazdružljivo povezano s prakso, tj. nekaj, kar mora človek dejansko izkusiti oziroma doživeti.

Videli smo, da je bila glavna predpostavka Stcherbatskyja in njegovih intelektualnih dedičev, da je v zgodovini budistične filozofske misli v Indiji prišlo do treh »kopernikanskih obratov«, ki so s seboj prinesli korenito spremembo temeljnih postavk v teoretični stavbi budizma. Filozofija tretje epohe, kamor naj bi sodila Dignāga in Dharmakīrti, je po tej shemi radikalno drugačna od filozofije zgodnjega budizma, kar Stcherbatskyju omogoči zagovarjati tezo, da budistična (epistemološka) logika ni neposredno povezana $\mathrm{z}$ - če uporabimo Stcherbatskyjev izraz - »budizmom kot religijo«, tj. »z naukom o poti, ki vodi do odrešitve«. Z drugimi besedami, pri Dignāgi in Dharmakīrtiju naj bi prišlo do radikalnega preloma s starejšo budistično tradicijo, po kateri je teorija (budistična filozofija) le pomagalo praksi (iskanje razsvetljenja), torej sredstvo, ki iskalcu resnice sicer lahko pomaga na njegovi duhovni poti, ne more pa nadomestiti osebne izkušnje. V prejšnjih razdelkih smo pokazali, da je takšno pojmovanje zgodovine budistične filozofije napačno ali (vsaj) pretirano: kljub razlikam $\mathrm{v}$ miselnih sistemih, je budistične avtorje namreč vseskozi motivirala ravno želja, da bi se s svojo filozofsko mislijo vrnili $\mathrm{k}$ izvornemu Budovemu nauku in na pojmovni ravni pomagali osvetliti srž pristne budistične prakse. Morebitne kritične tendence - npr. Nāgārjunova kritika sarvāstivāde - so bile potemtakem usmerjene proti naukom, v katerih so kritiki videli odklon od naukov izvornega budizma, ne pa njihovo zvesto uprimeritev, in so v bistvu želele rekonstruirati Budovo temeljno sporočilo.

Kot smo videli, je bilo eno od konceptualnih orodij, h kateremu se je v svojih prizadevanjih znova in znova zatekala budistična misel, pojem dveh resnic. S pomočjo omenjenega pojma so avtorji madhyamake in yogācāre skušali misliti dozdevno protislovnost, prisotno $\mathrm{v}$ abhidharma literaturi - namreč dozdevno protislovnost med ubesedljivim in neubesedljivim delom Budovega nauka. 
Nāgārjunov nauk o praznini (śūnyatā) zato ni zagovor nihilističnega sistema, ki izpodbija možnost vsakršnega racionalnega diskurza kot takega, temveč opozorilo, da so $v$ zadnji instanci vsi teoretični sistemi (zaradi svoje utemeljenosti na jeziku in dihotomnem mišljenju) vselej nezadostni: so le pregovorni prst, ki kaže na luno (resnico), ne pa luna (resnica) sama. ${ }^{22}$ To seveda ne pomeni, da je racionalni diskurz irelevanten, saj nas prav ta diskurz opozori na obstoj (temeljne) resnice in nas usmeri $\mathrm{k}$ njej. Temeljna resnica pa je neubesedljiva zato, ker $\mathrm{v}$ njej pride do preseganja dihotomnega načina mišljenja: nastopi »intuitivna modrost «, v kateri na izkustveni ravni doživimo ne-dvojnost človeka in sveta oz. dejstva, da »sta človek in svet nedeljiva celota, človek je svet in svet je človek« (Hayes 1988, 18).

Čeprav presega razumske kategorije, pa nirvāṇa ni nekaj skrivnostnega ali ezoteričnega: ne gre za ekstatično ali zamaknjeno stanje zavesti, temveč za intuitivno vednost, ki sloni na »čisti« zaznavi oz. »zaznavanju stvari takšnih, kot so « in je posledica uporabe meditativnih tehnik. Glavni cilj meditativnih tehnik ${ }^{23}$ je urjenje in poglabljanje pozornosti in zbranosti (in ne vizije, transi, ekstaze ipd.), ki meditatorju postopoma razkrivata »vse tisto, kar so zakrivali pojmi, ideje, misli in sebične projekcije, vse tisto, kar je imel za 'svoj' jaz« (Hayes 1988, 36). Pri zbranem opazovanju ostane »le sedanjost - čista izkušnja«, v kateri »ni nobenih sebičnih nagnjenj - je onkraj dualnosti« (Hayes 1988, 31). »Osvoboditev« torej človek doseže »le takrat, ko je zaznava čista, ko se v njej zrcali svet tak, kot je onkraj ocen, onkraj dobrega in zla« (Hayes 1988, 46). Modrost, ki je podlaga za doseganje nirvane, je v delu Visudhimagga oz. Pot očiščenja opisana takole:

Modrost prodre do prave narave stvari in prežene temo nevednosti, ki zakriva pravo naravo. Vedno spremlja čisto zaznavo, njena osnova pa je zbranost, ki je podana z besedami: kdor je zbran, pozna in vidi stvari take, kot so. (Visudhimagga $v$ Pečenko 1990, 57, moji poudarki)

${ }^{22}$ Gl. tudi opombo 16 zgoraj.

${ }^{23}$ Čeprav bi natančen prikaz budističnih meditativnih tehnik zahteval posebno razpravo, naj navedem le nekaj najpomembnejših dejstev. Pečenko v budistični tradiciji loči dva tipa meditativnih tehnik: "pot, na kateri se meditator trudi, da bi dosegel nibbāno«, pri kateri gre za sistematično razvijanje pozornosti (z osredotočenostjo na nek predmet, glas, predstavo itd.), in »pot, na kateri se [meditator] preprosto zaveda sedanjosti«, pri kateri gre za pozorno in nepristransko motrenje vseh pojavov, ki se porajajo med prakso. Kljub razlikam pa Pečenko poudarja, da obe poti »vodita do istega cilja« in sta potemtakem samo »dve zunanji obliki notranjega razvoja« (Pečenko 1990, 136). Intuitivno (izkustveno) modrost (prajñā) lahko namreč razvijamo bodisi tako, da najprej do popolnosti razvijemo čisto pozornost in zbranost, potem pa tako zbrani opazujemo pojavni svet in razvijemo modrost (prva pot); ali pa zbranost in modrost razvijamo vzporedno - ko pozorno opazujemo pojave, razvijamo zbranost, s katero poglabljamo intuitivno razumevanje (druga pot): »Na koncu obe poti pripeljeta do istega cilja [...] srečata [se] v izkušnji nibbāne« (Pečenko 1990, 59). 
Če strnemo: temeljna resnica (modrost $[$ prajñā] $)$ torej počiva na razvoju »čiste zaznave« (»videnju stvari takšnih, kot so«), ki jo dosežemo s pomočjo meditativnih tehnik (»razvoj pozornosti in zbranosti«): »čista izkušnja« leži onstran dihotomnih kategorij razuma in jezika (je neubesedljiva) in »ne presoja in analizira, ampak samo pozorno in zbrano sprejema celoto« (Hayes 1988, 31). Hayes ima torej prav, ko pravi, da se motijo tisti, ki pojem nirvāne povezujejo z »odrešiteljem«, obenem pa nima prav, ko oporeka možnosti obstoja vednosti, ki presega domeno pojavnega in racionalnega (Hayes 1988, 35). Vendar to ne pomeni, da je cilj budistične prakse anti-racionalen in/ali anti-empirističen - gre le za to, da v poslednji instanci ti pojmi nimajo nobenega smisla, medtem ko mora na ravni običajne resnice vsaka izjava biti logično koherentna. ${ }^{24}$

In ravno na tej točki lahko pričnemo $\mathrm{z}$ očrtom vloge, ki jo $\mathrm{v}$ budističnem sistemu zasedata epistemologija in logika. Izkaže se, da je pri tem namen, ki ga je logiki na prvem mestu pripisoval Dharmakīrti - kako priskrbeti »racionalno podlago budistični dogmatiki« (Hayes 1988, 33) -, še najmanj pomemben. Bistveno pomembnejše je nadaljevanje in nadgraditev teorije o dveh resnicah, ki se je vila skozi celotno prejšnjo budistično tradicijo. Dignāga in Dharmakīrti sta s svojim delom natančneje pojmovno (!) razmejila ${ }^{25}$ to, kar je začel Nāgārjuna in sta nadaljevala Asanga in Vashubandu: polje temeljne resnice, ki je v domeni zaznave in jo lahko dosežemo $\mathrm{z}$ meditativno prakso, in polje običajne resnice, ki je v domeni razuma in jo lahko dosežemo s pravilnim logičnim sklepanjem. Pod drobnogled vzameta področje običajne resnice in očrtata meje razuma ter znotraj teh meja formulirata pravilne oblike sklepanja. Na ta način natančnejše opredelita, $v$ kolikšni meri in na kakšen način je običajna resnica lahko resnična - resnična je, v kolikor deleži na temeljni resnici (zaznava) in se pokorava pravilom pravilnega sklepanja. ${ }^{26}$ Logika in mistika v njunem modelu tako nista nekaj ločenega, ampak sta tesno prepleteni: na skrajnem robu logike se razpira horizont mističnega oz. kjer se konča argumentacija, se prične meditacija.

\footnotetext{
${ }^{24}$ Pravzaprav bi lahko celo rekli, da je budistična pozicija ultra-empiristična, saj jo zanimajo pojavi kot taki, tj. brez vseh primesi naše ego-strukture.

${ }^{25} \mathrm{Na}$ ravni prakse obstaja namreč samo ena raven: svet, ki motri svet (ne-dvojna vednost).

${ }^{26}$ Strogo gledano, lahko v budizmu govorijo resnico samo osebe, ki so dosegle nirvāṇo, kajti le one res vidijo stvari takšne, kot so, kar pomeni, da tudi njihove besede (trditve) deležijo na tej resničnosti. Kljub temu pa tudi njihove izjave niso nezmotljive, toda ne zaradi tega, ker bi bila njihova vednost pomanjkljiva, temveč zato, ker jezik kot tak zavoljo lastne strukture nikoli ne more zadovoljivo izraziti temeljne resnice.
} 
»Čista« zaznava pri Dignāgi in Dharmakīrtiju pa ni le »transcendentalni pogoj« vsega izkustva, tj. nedosegljiva limita zaznavne zmožnosti, kot trdi Stcherbatsky $(1962,183)$, temveč gre za realno izkustvo. Stcherbatsky na nekem mestu navaja sledečo Dharmakīrtijevo izjavo:

Človek, ki v meditaciji zre v modro zaplato, zaznava modro, vendar pri tem ne ve, da gre za modro barvo; o predmetu ve le to, da gre za predmet, čeprav ne ve, za kakšen predmet gre. (Stcherbatsky 1962, 153)

Hayes pa navaja Dignāgovo misel:

Izvedenci $v$ meditaciji vidijo le predmet kot tak, njihova zaznava pa je prosta vseh vnaprejšnjih predstav, ki so posledica učiteljevih naukov. Zaznava predmeta kot takega, značilna za izvedence $\mathrm{v}$ meditaciji, katerih zaznave niso skalile vnaprejšnje predstave njihove tradicije, je prav tako zaznava. (Hayes 1988, 136)

$\mathrm{V} » c ̌ i s t i ~ z a z n a v i \ll$ izkusi meditator »temeljno (neubesedljivo) resničnost«. Vendar, kot pravilno pripomni Stcherbatsky, gre pri tem za dvojnost (zaznava-resničnost) »le na logični ravni«. Na končni »translogični ravni« namreč pride do »zlitja subjekta in objekta«, tj. do »razvoja intuitivne modrosti« oz. »izkustva nirvāne» (Stcherbatsky 1962, 202). Ne smemo namreč pozabiti, da tudi Dignāgov in Dharmakīrtijev model operira na ravni razuma (običajne resnice), kar pomeni, da nas lahko samo usmeri proti temeljni resnici, ne moremo pa je z njegovo pomočjo doživeti.

Še en zanimiv predlog o tem, kako bi logično-epistemološka vprašanja lahko usmerjala proti resnici, in sicer na še bolj neposreden način (kot sestavni del meditativne prakse), ponudi Hayes v svojem »skeptičnem branju Dignāge«. Znano je, da so pravila veljavnega sklepanja, ki jih je postavil Dignāga, tako zelo stroga, da jim lahko zadosti le malo število izjav. Večina kasnejših komentatorjev vključno z Dharmakīrtijem - je videlo v tem pomanjkljivost njegovega sistema in so jo zato skušali na različne načine odpraviti. Hayes pa nasprotno predlaga, da je to, kar se prvotno morda zdi kot pomanjkljivost, pravzaprav največja odlika njegovega sistema: $\gg Z$ drugimi besedami, možno je, da je Dignāga oblikoval kanon gotovosti, ki mu ne more zadostiti nobena izjava. V ozadju postavitve tako strogih kriterijev gotovosti bi se lahko skrivala želja po vzpostavitvi še ene oblike budističnega svarila pred tem, da gojimo kakršnakoli mnenja in dajemo kakršnekoli izjave, ne da bi se obenem jasno zavedali, kako šibka je upravičenost naših prepričanj« (Hayes 1988, 166). 
Glavno sporočilo Dignāge bi potemtakem bilo, da so »edino, kar je gotovo, zaznave, ki jih imamo v tem hipu«, medtem ko je to, kar te zaznave »uprimerjajo«, "predmet ugibanja«. Vprašljiv postane celo proces »identifikacije« in podobnih, dozdevno primarnih spoznavnih procesov (Hayes 1988, 166). Ena od nalog budistične epistemologije je, da »nam omogoči, da na zelo počasen način pretresemo približek korakov v miselnem procesu, ki jih običajno preidemo zelo naglo«: ko naše miselne konstrukte razčlenimo v »temeljne enote«, velikokrat ugotovimo, da so bile naše nereflektirane intuicije »zelo napačne«. Logika potemtakem ni samo »sredstvo za upravičevanje budističnega nauka« (Dharmakīrti), temveč tudi - in predvsem - pripravno orožje za boj proti »dogmatizmu in predsodkom«. Ker zelo malo izjav izpolni stroge Dignāgove kriterije, ni nihče »imun za napake, ki zahtevajo popravke v luči novoodkritih resnic«. Ker »ne moremo popolnoma zaupati naukom nekega učitelja ali učiteljske tradicije«, leži pot do »osvoboditve« v »naših rokah«. Poleg tega je - kot smo videli v prejšnjem razdelku - vsak dogodek, ki ga zaznavamo, edinstven: zaznava se nanaša izključno na to, kar je »resnično« in »prisotno«, na posamičnosti, ki jih kot take ne moremo primerjati z drugimi posamičnostmi. Nenehno odkrivanje »tega, kar je prisotno ta hip« pa je ena od najznačilnejših oblik »budističnega urjenja pozornosti«, in eden od načinov, kako se ubranimo »vnaprejšnjih predstav«, je, da jih podvržemo »strogim standardom logike« (Hayes 1988, 168). $\mathrm{Z}$ drugimi besedami, epistemologija pri Dignāgi k nirvāṇi ne prispeva le posredno ( $\mathrm{tj}$. V negativnem smislu razmejevanja logičnega od mističnega), temveč tudi neposredno: ni torej le način, da posameznika napotimo k meditativnim tehnikam, temveč tudi sestavni del »meditacijo razvijanja pozornosti (vipassana)«.

Vidimo torej, da so poskusi razlage logično-epistemološke budistične šole, ki slednjo protipostavljajo prejšnjim miselnim tokovom, prekratki, zaradi česar je temeljna struktura sistema, ki ga ta šola postulira (zaznava versus razum), v takšnih prikazih videti precej naključna in poljubna. Dejansko pa sta bila Dignāga in Dharmakīti dediča intelektualne zapuščine, ki je na pojmovni ravni s pomočjo teorije o dveh resnicah skušala precizirati bistvo Budovega nauka kot poti, ki vodi k nirvāṇi, in je zato njuno delo le nadaljevanje že začrtanih miselnih smernic. Dignāga in Dharmakīrti sta na teoretični ravni dodelala in celo radikalizirala razcep med dvema sferama vednosti - konvencionalno (razum) in temeljno (zaznava) -, da bi ju na praktični ravni lahko še bolj zbližala oziroma celo premostila: njun epistemološko-logični model je namreč kot nekakšen splav, katerega namen je povezati dva radikalno različna bregova: argumentacijo in 
meditacijo, samsāro in nirvāṇo, logiko in mistiko. $\mathrm{V}$ tem oziru spominja na Wittgensteinovo prispodobo logike kot lestve, po kateri lahko priplezamo do sfere mističnega in jo lahko nato tudi odvržemo. Vendar pa lahko to storimo šele, ko smo preplezali celotno pot - in nič prej.

\section{Summary}

Studies in Indian Buddhist philosophy have been predominantly influenced by two different schools of thought: the first (and older) school perceives the development of Buddhist philosophical thought as a highly dialectical process, i.e. as a series of discrete phases that evolved as a reaction to their intellectual predecessors (Buddhist monism as a reaction to Buddhist pluralism etc.), while the second (and younger) school emphasizes a much more continuous development of Buddhist philosophy, claiming it to be more akin to an ongoing process in which certain fundamental philosophical themes had been gradually modified and improved upon. In the present article, we use the conceptual framework of the latter (younger) school of thought to shed light on certain philosophical themes that are present in the Buddhist logical-epistemological school, especially the so-called theory of two truths. We then attempt to show that the logical-epistemological system of Dignāga in Dharmakīrti was much more strongly interrelated with previous trends of Buddhist philosophy than is assumed by the "dialectical" school, and that, in order to gain the proper understanding of its origin, purpose and structure, we must place it into the broader context of Buddhist theory and practice, whose main goal is to pave the road towards the attainment of nirvanna. Thus, the main thesis of the present article is that not only are there no inconsistencies between the logical-epistemological reflections and spiritual elements in Indian Buddhism, but that, in fact, they are inextricably interconnected: they were both designed with the purpose of helping the individual to free him- or herself from the bonds of the phenomenal world, which is in stark contrast with the views of several older authors. 
Sebastjan VÖRÖS: Misel in neizrekljivo v budistični logično-epistemološki šoli

\section{Literatura}

Arnold. Dan. 2005. Buddhists, Brahmins, and Belief: Epistemology in South Asian Philosophy of Religion. New York: Columbia University Press.

Eliot, Charles S. 2010 (1921). Revered Wisdom: Buddhism. New York: Sterling Innovation.

Harris, I. C. 1991. The Continuity of Madhyamaka and Yogācāra in Indian Mahāyāna Buddhism. Leiden: E. J. Brill.

Hayes, Richard P. 1988. Dignaga on the Interpretation of Signs. Dordrecht: Kluwer Academic Publishers.

Kalupahana, David J. 1987. The Principles of Buddhist Psychology. New York: State University of New York.

King, Richard. 1999. Indian Philosophy: An Introduction to Hindu and Buddhist Thought. Edinburgh: Edinburgh University Press.

Pečenko, Primož. 1990. Pot pozornosti: Osnove budistične meditacije. Ljubljana: Domus.

Stcherbatsky, F. Th. 1962. Buddhist Logic, vol. I in II. New York: Dover Publications.

The Cowherds. 2011. Moonshadows: Conventional Truth in Buddhism. Oxford: Oxford University Press.

Ule, Andrej. 2004. 'O budistični logiki.' Azijske in afriške študije 8(3): 1-25. 